\title{
Asterina dallasica Petrak - a new record to India
}

V.B. Hosagoudar, M.C. Riju and C. Uma Maheswari*

Tropical Botanic Garden and Research Institute, Palode 695 562, Thiruvananthapuram, Kerala.

*Division of plant pathology, Indian Agriculture Research Institute, New Delhi 110012.

vbhosagoudar@rediffmail.com

Summary: Asterina dallasica infecting the leaves of Trema orientalis has been collected from Manandhavady region of Wayanad district in Kerala state and has been described and illustrated in detail. This species is being reported for the first time from India.

Key words: Asterina, Trema, Kerala, India

Introduction

During a survey of the folicolous fungi in the montane forests of Kerala state, black mildew infected leaves of Trema orientalis growing near Pazhassi tomb, Manandhavady, Wayanad were observed. Microscopic examination of the fungus revealed that it is hitherto unrecorded species of the genus Asterina from India.

Asterina dallasica Petrak, Sydowia 8:14, 1954.

Colonies epiphyllous, scattered, up to $3 \mathrm{~mm}$ in diameter. Hyphae straight, flexuous to crooked, branching irregular at acute to wide angles, loosely reticulate, cells $11-26 \times 6-11 \mu \mathrm{m}$. Appressoria scattered, unicellular, alternate, unilateral, about

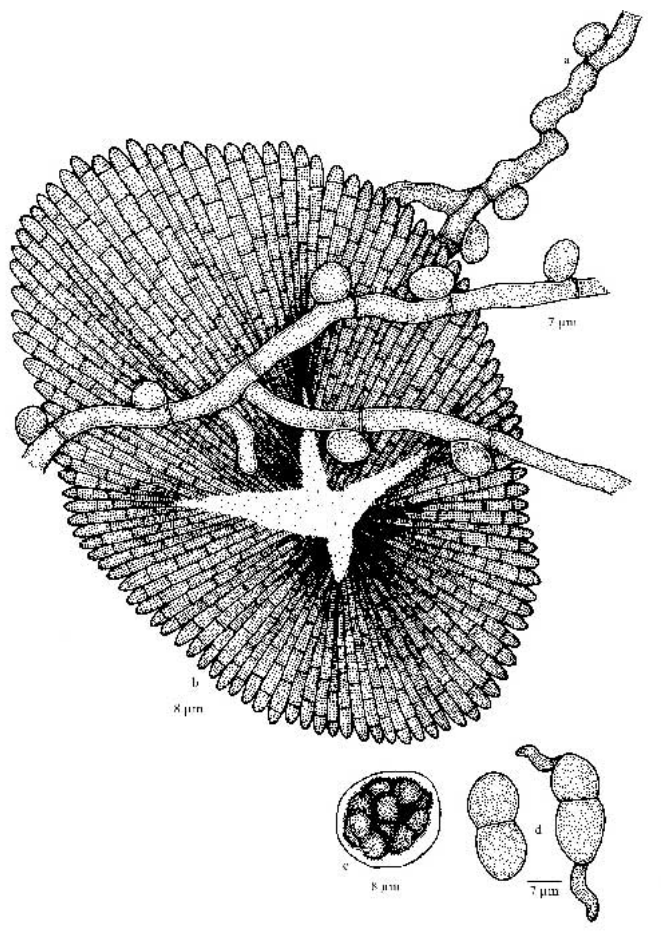

Fig. 1 a. Appressoriate mycelium,

b. Thyriothecium, c. Ascus, d. Ascospores.
$2 \%$ opposite, antrorse to subantrorse, globose, mammiform, mostly entire, rarely angular to crenately lobate, 6-11 $\mu \mathrm{m}$ in diameter. Thyriothecia closely scattered, orbicular, up to $115 \mu \mathrm{m}$ in diameter, stellately dehisced at the centre, margin fimbriate; asci globose, octosporous, bitunicate, up to $26 \mu \mathrm{m}$ in diameter; ascospores brown, uniseptate, constricted at the septa, 17-22 x 6-11 $\mu \mathrm{m}$, wall smooth.
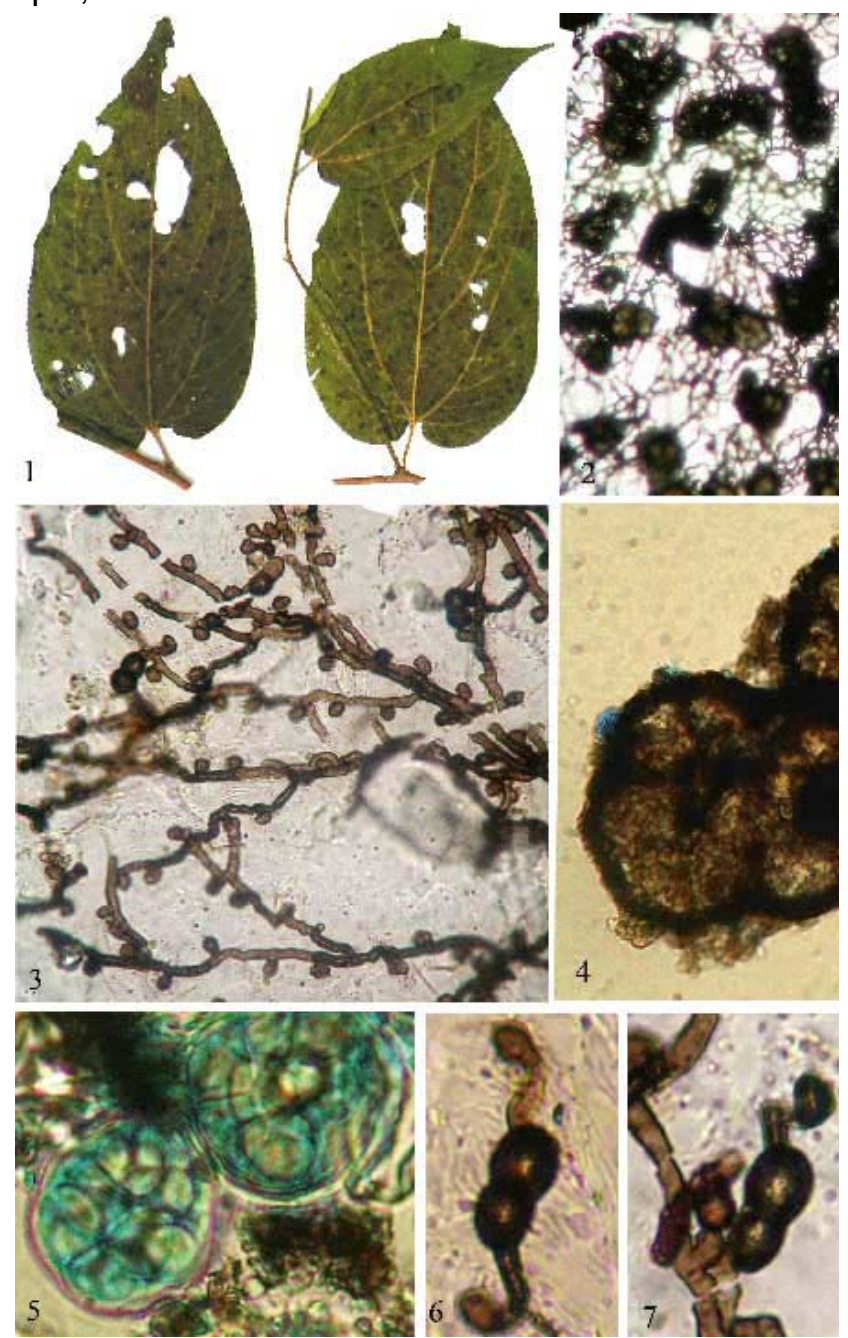

Plate. I. Asterina dallasica Petrak.

1. Infected leaves; 2. Mycelial colony with thyriothecia; 3. Appressoriate mycelium;

4. Thyriothecia with exposed asci; 5. Asci;

$6 \& 7$. Germinating ascospores.
iSee (C) category: Research article Indian Society for Education and Environment
"Asterina dallascica Petrak- a new record to India" by Hosagoudar et al. 
Materials examined: on leaves of Trema orientalis (L.) Blume (Ulmaceae), Manandhavady, Wayanad, Kerala, India. Nov. 9, 2007; M.C. Riju TBGT 3045 (Fig.1 \& Plate 1)

Asterina celtidicola Henn., A. dallasica Petrak and $A$. sponiae Racib. are known on Celtis, Trema and Sponia species, respectively. The present collection matches well with that of assigned species. This species was known on Trema species from Borneo Islands (Petrak, 1954; Hosagoudar \& Abraham, 2000) and is being reported here for the first time from India (Bilgrami et al., 1992, Jamaluddin et al., 2004). This reveals an affinity between the fungal flora of Wayanad and Borneo Islands.

\section{Acknowledgements}

We thank Dr. S. Ganeshan, Director, Tropical Botanic Garden and Research Institute, Palode, Thiruvananthapuram, Kerala for providing the facilities.

\section{References}

1. Bilgrami KS, Jamaluddin $S$ and Rizwi MA (1991) Fungi of India. List and References. Today and Tomorrow's Printers \& Publishers, New Delhi, pp.1-798.

2. Hosagoudar VB and Abraham TK (2000) A list of Asterina Lev. species based on the literature. J. Econ. Taxon. Bot. 24, 557-587.

3. Jamaluddin, GMG and Ojha BM (2004) Fungi off India (1989-2001). Scientific Publishers, Jodhpur, (India).

4. Petrak F (1954) Beilrage Zur Pilzflora Von Britisch Nord, Borneo. Sydowia. 8,12-26. 